\title{
STRATEGI MENYINDIR PADA VIDEO YOUTUBE SENGKLEKMAN OFFICIAL DAN RELEVANSINYA TERHADAP PEMBALAJARAN BAHASA INDONESIA
}

\section{SATIRICAL STRATEGY ON THE SENGKLEKMAN OFFICIAL YOUTUBE VIDEO AND ITS RELEVANCE TOWARDS INDONESIAN LEARNING}

\author{
Intan Pradana ${ }^{1}$, Idhoofiyatul Fatin ${ }^{2 *}$, M. Ridlwan ${ }^{3}$ \\ Pendidikan Bahasa dan Sastra Indonesia, Universitas Muhammadiyah Surabaya, \\ Indonesia ${ }^{1,2,3}$ \\ intan.pradana20@gmail.com ${ }^{1}$, idhofatin.pbsi@fkip.um-surabaya.ac.id ${ }^{2}$, \\ iezhaqlagi@gmail.com ${ }^{3}$ \\ *penulis korespondensi
}

\begin{tabular}{ll}
\hline Info Artikel & ABSTRAK \\
\hline Sejarah artikel: & Penelitian ini bertujuan untuk mendeskripsikan wujud strategi menyindir \\
Diterima: & pada video youtube Sengklekman Official dengan menggunakan teori \\
6 Juli 2021 & strategi off record Brown \& Levinson. Sengklekman Official merupakan \\
Direvisi: & chanel youtube yang menayangkan kartun humor tentang keluh kesah \\
11 Juli 2021 & masyarakat yang diintepretasikan melalui kehidupan tokoh Ian dan teman- \\
Disetujui: & temannya. Metode yang digunakan dalam penelitian ini adalah deskriptif \\
15 Juli 2021 & kualitatif dengan teknik simak catat. Berdasarkan hasil penelitian, \\
& ditemukan penggunaan strategi off record, yaitu give hint, give association \\
Kata kunci: & clues, presuppose, understate, overstate, use tautologies, be ironic, use \\
strategi menyindir, & metaphors, use retorical question, be vague, give over-generalize, dan \\
sengklekman, strategi & displace H. Di antara strategi menyindir yang digunakan, strategi off record \\
off record & overstate dan displace H adalah yang paling dominan. Hal tersebut \\
& dikarenakan tuturan dalam video Sengklekman Official cenderung berlebih- \\
& lebihan dan mengandung tuturan yang tidak mengacu kepada lawan tutur \\
& secara langsung. Dalam pembelajaran Bahasa Indonesia, hasil penelitian ini \\
& relevan dengan materi teks anekdot untuk mendukung tercapainya KD 3.5, \\
& 4.5, 3.6, dan 4.6 di kelas X SMA.
\end{tabular}

\begin{tabular}{ll}
\hline Article Info & ABSTRACT \\
\hline Article history: & This study aims to describe the form of a satirical strategy on the \\
Received: & Sengklekman Official youtube video using Brown \& Levinson's off record \\
6 July 2021 & strategy theory. Sengklekman Official is a YouTube channel that broadcasts \\
Revised: & humorous cartoons about public complaints which are interpreted through \\
11 July 2021 & the figure lives of Ian and his friends. The method used in this research is \\
Accepted: & descriptive qualitative with note-taking technique. Based on the results of \\
15 July 2021 & the study, it was found the use of off record strategies, namely give hint, \\
& give association clues, presuppose, understate, overstate, use tautologies, be \\
Keyword: & ironic, use metaphors, use rhetorical questions, be vague, give over- \\
satirical strategy, & generalize, and displace H. In Among the satirical strategies used, the \\
seklekman, strategy off & strategy of off record overstate and displacement H is the most dominant. \\
record & This is because the speech in the Sengklekman Official video tends to be \\
& excessive and contains speech that does not refer to the interlocutor directly. \\
& In learning Indonesian, the results of this study are relevant to anecdotal text \\
& material to support the achievement of KD 3.5, 4.5, 3.6, and 4.6 in class X \\
& Senior High School.
\end{tabular}




\section{PENDAHULUAN}

Kartun identik dengan hiburan. Hal tersebut sesuai dengan pernyataan Rowden (2013) yang menyebutkan bahwa kartun salah satu fungsi kartun adala memberikan hiburan bagi pembaca media massa. Meskipun sebagai hiburan, kartun juga dianggap sebagai cara yang efektif untuk mengolok-olok sesama, lembaga, dan diri sendiri karena mampu memberikan informasi yang cepat dan berdampak menyenangkan, spontanitas, serta citra popular (Davis, 2017; Ezell, 2016; Melton, 2018; Weisgerber, 2019). Berkaitan dengan hal tersebut, Suprayuni dan Juwariyah (2019) mempublikasikan hasil penelitiannya tentang humor dan satire dalam media massa yang menunjukkan hasil bahwa kartun tidak hanya dimaksudkan sebagai humor tetapi juga efektif sebagai alat untuk mengkritik. Bahkan disimpulkan juga bahwa kartun merupakan bentuk pewacanaan dan pendidikan bagi masyarakat.

Salah satu kartun yang sarat akan humor serta kritik atau sindiran sebagai kontrol kekuasaan pemerintah juga terdapat pada video youtube Sengklekman Official. Karena bersifat mengibur namun juga berkaitan dengan kehidupan sehari-hari penonton, chanel ini memiliki ratusan subscriber. Keunikan video pada chanel ini adalah dihadirkannya tokoh-tokoh unik yang lucu tapi mampu mengkritisi berbagai macam kebijakan pemerintah dan kehidupan nyata lainnya. Yang menarik di sini adalah, karena dibungkus dalam kartun humor, tujuan menyindir ini pun menjadi tontonan yang mengasyikkan dan tidak menimbulkan protes atau memberikan efek tersakiti. Hal tersebut sesuai dengan pengertian menyindir pada KBBI daring edisi 3 yang menyebutkan bahwa menyindir adalah mengkritik (mencela, mengejek, dan sebagainya) seseorang secara tidak langsung atau tidak terus terang. Ketidakterusterangan itu dalam lingistik erat kaitannya dengan strategi off record atau tidak langsung yang diperkenalkan Brown dan Levinson.

Brown dan Levinson (1987) mengemukakan bahwa strategi ini disebut pula strategi tidak langsung dengan membiarkan lawan tutur memututuskan sebuah tafsiran. Sedangkan menurut Nadar (2009), stretegi ini ialah strategi pengungkapan yang tidak transparan dalam bentuk tuturan yang diungkapkan secara tidak langsung sehingga menghasilkan intepretasi yang berbeda-beda pada tiap orang. Strategi ini dijadikan pengungkapan yang sifatnya tidak langsung karena perlu adanya intepretasi ungkapan yang tidak hanya kata tapi juga mengamati situasi percakapan saat uturan diucapkan.

Menurut brown dan Levinson (1987), strategi off record memiliki 15 sub strategi. Kelima belas strategi itu meliputi (1) memberi petunjuk (give hint), (2) memberikan petunjuk yang berasosiasi (give association clues), (3) perkiraan atau prasangkaan (presuppose), (4) mengecilkan lawan tutur (understate), (5) melebihlebihkan tuturan (overstate), (6) menggunakan tautologi (use tautologies), (7) menggunakan pertentanganlkontradiksi (use contradictions), (8) menggunakan ironi (be ironic), (9) menggunakan metafora (use metaphors), (10) menggunakan pertanyaan retoris (use retorical), (11) menyatakan tuturan secara ambigu (be ambiguous), (12) menyatakan sesuatu dengan samar-samar (be vague), (13) menyatakan

penyeragaman/ 
menggenaralisasi (over generalize), (14) menggantikan posisi lawan tutur (displace $H$ ), dan (15) menggunakan kalimat elipsis (be incompleteuse).

\section{METODE}

Metode penelitian yang digunakan dalam penelitian ini adalah penelitian deskriptif kualitatif. Bogdan dan Taylor (Moleong, 2013:4) menyebutkan bahwa metode penelitian kualitatif merupakan prosedur penelitian yang menghasilkan sebuah data deskriptif yang berupa kata-kata tertulis atau lisan dari orang-orang dan perilaku yang diamati. Metode ini dipilih karena data yang diolah berupa kata yang diambil dari video pada channel youtube "Sengklekman Official". Karena berupa video, teknik pengambilan datanya menggunakan simak catat. Kemudian, teknik analisis data yang digunakan adalah teknik analisis kualitatif dari Miles dan Huberman (Sugiyono, 2016: 247-253) dengan tiga langkah dalam menganalisis data yaitu data reduction (atau reduksi data), data display (atau penyajian data), dan conclution drawing/ verification (penarikan kesimpulan).

\section{HASIL DAN PEMBAHASAN}

Sindiran termasuk ke dalam tuturan tidak langsung. Oleh karena itu, strategi menyindir yang dipergunakan adalah strategi off record yang merupakan teori dari Brown dan Levinson. Strategi off record menurut Brown dan Levinson (1987: 211) akan terjadi jika tidak memungkinkan menggunakan tuturan langsung. Strategi Off Record merupakan bagian dari strategi kesopanan. Strategi off record merupakan strategi melakukan FTA (face threatening act) atau tindakan pengancaman muka yang dilakukan secara tidak langsung dengan membiarkan lawan tutur memutuskan tafsiran dari apa yang dituturkan oleh penutur.

\section{Strategi Off Record dengan Memberi Petunjuk (Give Hint)}

Strategy off record dengan memberi petunjuk akan digunakan untuk mengimplisitkan informasi kepada lawan tutur. Pemberian petunjuk dilakukan dengan mengemukakan suatu alasan untuk melakukan tindakan, bisa dikatakan seperti memberi syarat. Berikut adalah tuturan strategi menyindir secara tidak langsung dengan memberi petunjuk (give hint) pada video yang berjudul "Ghibahin sahabat dekat_Ghibah".

Data 1

(1d) Samsudin: "Oh ku ga ada kerjaan apa yang bikin game quiz sengklek?. Bukan dibikin quiz yang membuat kita makin pinter, malah bikin sengklek."

(1e) Ian: "INI GAME KITA WOYY, PROMOSI YANG BAIK-BAIK !!"

(1f) samsudin: "ohh gitu.. OHKU KEREN KALI GAMENYA, WAJIB BANGET NIH KITA $D O W N L O A D \quad$ UNTUK MENEMANI KESUNTUKAN KITA DI RUMAH..(nada rendah)".

StMy/SOR1/tact/Dt5/1f /00.41-00.56

Tuturan pada data no 1 pada tuturan (1f) yang dituturkan oleh tokoh samsudin merupakan bentuk tuturan strategi menyindir yang menggunakan strategi menyindir secara tidak langsung dengan memberi petunjuk (give hint) karena apa yang dikatakan tokoh samsudin pada (1f) merupakan 
tuturan yang memiliki makna implisit atau adanya isyarat, meskipun maknanya tidak terlihat secara jelas. Dapat dimungkinkan makna pada tuturan tersebut, orang yang selalu berada di dalam rumah akan membuat seseorang mengalami kesuntukan, kemudian di kemas seelok mungkin dengan tuturan (1f).

Pada tuturan ini dapat dilihat bahwa meskipun tokoh Samsudin mengalami kesuntukan tetapi tetap memberikan tuturan untuk memaksimalkan keuntungan bagi orang lain dengan wacana bermain game dapat menemani selama berda di rumah untuk mengikuti anjuran pemerintah.

Fenomena dalam ilustrasi ini cukup mewakili fenomena masyarakat selama mengikuti anjuran pemerintah untuk berdiam diri di rumah yang dapat dimungkinkan akan mengalami kesuntukan.

\section{Strategi Off Record dengan Memberikan Petunjuk yang berasosiasi (Give Association Clues)}

Strategi ini dapat digunakan dengan syarat hendaknya peserta tutur memiliki pengalaman dan pemahaman yang sama. Tujuannya digunakan untuk mengasosiasikan sesuatu yang sudah diketahui lawan tutur itu sendiri. Berikut adalah tuturan strategi menyindir secara tidak langsung dengan memberi petunjuk yang berasosiasi (give association clues).

Data 2

(1j) Samsudin: "Tadi kan Om lihat, Aziz sama kana.."

(11) Samsudin: "Ternyata mereka berghibah di belakang kamu?" (1m) Ian: "HAH? Ga mungkin! (kaget). Mereka kan sahabat aku Om."

(1n) Samsudin: "Yeeee, ga percayalah dibilangin, buktiin aja.

(1q) Ian: "Ternyata bener kayak om bilang". (Kana dan Aziz ghibah di belakang punggung Ian).

StMy/SOR2/appo/Dt5/1 $\mathrm{m} / 01.00-01.25$

Tuturan bernomor 2 tersebut dituturkan oleh tokoh Ian dan Samsudin pada video berjudul "Ghibahin Sahabat Dekat_Ghibah". Tokoh samsudin memberitahukan bahwasannya tokoh Ian sedang dijadikan topik pembicaraan atau bahan ghibahan di belakang tokoh ian, tetapi tokoh ian tidak percaya karena seorang sahabat tidak mungkin membicarakan sahabatnya sendiri di belakang. Dalam tuturan ini, Samsudin memberitahukan kebenaran bahwa memang Aziz dan Kana berbicara di belakang Ian. Akan tetapi, makna di belakang bukan bermakna berbicara tanpa sepengetahuan tokoh Ian, melainkan berbicara di belakang punggung ian "dibelakang" dalam arti sebenarnya.

Berdasarkan data bernomor 2, tuturan tersebut merupakan tuturan strategi menyindir secara tidak langsung dengan memberi petunjuk yang berasosiasi (give association clues) dalam strategi ini penutur dan lawan tutur diharuskan memiliki pengetahuan dan pengalaman yang sama, seperti pada verba 'sahabat' yang sudah lazim digunakan sehingga makna sahabat sudah banyak orang memahaminya. Tuturan ini menyindir fenomena orang yang dalam ikatan persahabatan sering melakukan 'ghibah' terhadap sahabatnya. Padahal 
sahabat adalah orang yang sudah lama dikenal dan sering berhubungan jadi tak elok rasanya jika melakukan pembicaraan apalagi topiknya buruk di belakang sahabat atau orang yang sedang dibicarakan.

\section{Strategi Off Record dengan perkiraan atau prasangkaan (Presuppose)}

Strategi ini menggunakan presuposisi yang mempresupisisikan maksud dari penutur. Cara penggunaannya dengan memberian isyarat kepada lawan tutur. Berikut adalah strategi dengan perkiraan yang ditemukan pada video berjudul "Apakah ini episode terakhir ian sengklekman?_diculik preman”.

Data 3

(2c) Penculik 2: (Makan permen, dengan ekspresi cuek) "Orangnya disebelah sini. Anak buahku yang pintar".

(2d) penculik 1: "Owwhh" (langsung balik arah, dan menghadap ian. Karna tadi saat berbicara tanpa menghadap ian). "Woy Kampret! Sapa yang ikat ?!."

StMy/SOR3/mode/Dt11/2c/01. 00-01.04

Tuturan pada data 3 terjadi ketika tokoh Ian sedang diculik kemudian minta dilepaskan. Tetapi ternyata tokoh Ian hanya didudukan di atas kursi seperti yang dilakukan pada penculikan pada umumnya. Penculikan yang dialami tokoh Ian tanpa diikat. Sehingga penculik 1 memarahi tokoh Ian "siapa yang ikat ?!!", tetapi penculik 1 salah menghadap ketika memarahi tokoh Ian. Sehingga penculik 2 bertutur "orangnya disebelah sini. Anak buahku yang pintar". Kemudian penculik 1 sadar kalau arahnya salah, dan mengulangi lagi dialog pertanyaan "siap yang ikat ?!!".

Data bernomor 3 tersebut Merupakan strategi sindiran secara tidak langsung dengan perkiraan atau prasangkaan (presuppose), yakni adanya pengungkapan presuposisi dalam maksud penutur. Seperti halnya pada kata "anak buahku yang pintar" dalam artian sebenarnya dimaknai sebagai orang/bawahan yang memiliki kepandaian dalam berpikir (KBBI V). Pada tuturan tersebut, pintar yang dimaksud adalah karena kebodohan yang dilakukan penculik 1 sehingga diingatkan oleh penculik 2. Tokoh penculik 2 yang meskipun memiliki peran sebagai 'bos' tokoh ini tetap meminimalkan rasa hormat pada diri sendiri dengan bertutur "anak buahku yang pintar"

\section{Strategi Off Record dengan mengecilkan lawan tutur (Understate)}

Strategi ini dilakukan dengan menyatakan hal yang kurang dari sebenarnya dengan memberikan batasan pada sejumlah atribut untuk mengimplikasikan sesuatu yang buruk dengan menggunakan ungkapan yang lebih halus, tetapi penutur memberi informasi yang kurang jelas/sedikit. Strategi ini ditemukan pada video yang berjudul "Rahasia sunda empire_Sunda Emperan".

Data 4

(2h) Pembawa acara televisi: "(dengan nada pelan, seperti orang sudah tua) Dan kamu bilang sunda emperan bisa menghentikan perang nuklir....apa benar?"

(2i) Rangga: "Yap. Benar sekali! Kerajaan kita bisa 
menghentikan perang nuklir tersebut"

(2j) Pembawa acara: "Caranya ?"

(2k) Rangga : "Aplikasi TOK TIK.

(21) Pembawa acara: "Kita rehat dulu..."

(DU) Muncul Pengiring suara, sembari menunjukan tayangan ketika rangga sudah mendekam dalam bui.

(2m) pengiring Suara : "Dan akhirnya rangga pun dimasukan ke dalam sel, dikarenakan sudah meresakan warga dan mengubah sejarah pada wikipedia. Sayangnya, rangga tidak memiliki kartu kesempatan penjara monopoli. Di sisi lain, cinta sudah menikah dengan Pangeran king of king TAMAT". StMy/SOR4/simp/Dt2/2m/02.

13-03.04

Tuturan terjadi ketika tokoh Rangga dari kerajaan Sunda Emperan sedang berdialog interaktif dengan pembawa acara dalam program televisi. Tokoh Rangga merupakan tokoh pendiri kerajaan Sunda Emperan yang diciptakan karena desakan tokoh Cinta yang merupakan kekasih tokoh rangga. Kemudian, tokoh tersebut diundang pada stasiun telvisi karena berisu sunda emperan dapat mencegah perang nuklir. Dan ketika tokoh rangga ditanya terkait cara, toko rangga menjawab dengan aplikasi "TOKTIK", penonton di rumah tercengang kemudian pembawa acara menampar tokoh rangga karena merasa tuturan rangga tidak dibenarkan adanya. Alhasil lewat tuturan pengisi suara, diketahui tokoh Rangga dijebloskan ke dalam penjara karena melakukan penipuan dan sudah merubah sejarah pada wikipedia. Tokoh rangga tidak dapat bebas dari penjara karena tidak memiliki kartu kesempatan bebas penjara yang biasanya digunakan dalam permainan monopoli.

Tuturan dalam data 4 ini jenisnya termasuk Strategi menyindir secara tidak langsung dengan mengecilkan lawan tutur (Understate) karena adanya atribut yang mengimplikasikan sesuatu yang buruk tetapi dikemas dengan ungkapan yang lebih halus seperti dalam tuturan $(2 \mathrm{~m})$ "Dan akhirnya rangga pun dimasukan ke dalam sel, dikarenakan sudah meresakan warga dan mengubah sejarah pada wikipedia". Tuturan tersebut dapat dimungkinkan memiliki maksud untuk melakukan kritikan atau sindiran terhadap suatu fenomena, salah satunya dari fenomena yang terjadi dalam kehidupan nyata terkait munculnya kerajaan baru kemudian raja baru beserta para pengikutnya saat ini dimasukkan ke dalam penjara karena tidak memiliki bukti jika kerajaan keraton agung sejagat di wilayah purwokerto tidak terdaftar.

\section{Strategi Off Record dengan cara melebih-lebihkan tuturan (Overstate)}

Strategi ini penutur melebihlebihkan tuturan dari yang seharusnya dapat dikatakan sama seperti gaya bahasa hiperbola, yang melebihlebihkan tuturannya sehingga tuturan tidak sesuai dengan kenyataan yang ada karena membesar-besarkan keaadan. Strategi tersebut ditemukan dalam video yang berjudul "Jualan Sate Ketemu Kuntilanak_Jualan Sate".

Data 5

(1a) Samsudin (tukang sate): "(sembari mengipas sate) satee..sateee. Satee..sateee. 
satee..sateee. Yaampun cukup berat aku miskin, padahal selama ini aku hemat kali jadi orang. Paling pengeluaran aku cuma untuk beli apartement, beli mobil ferrari, beli saham. Itu doang, ga pernah beli gundam atau barang mahal lainnya. Dikarenakan kondisi krisis terpaksa Om harus mencari uang sampingan, untung waktu masa muda Om yang mirip Jungkook BTS sempet jualan sambil kuliah, jadi punya pengalaman untuk berbisnis sate ini. Tapi ngomong-ngomong malam ini sepi kali lah, padahal baru jam 12 malam. Pada kemana lu orang-orang ?" (ditayangkan kalau samsudin berjualan di depan kuburan).

StMy/SOR5/gery/Dt4/1a/00.15 $-01.01$

Data 5 tersebut mengandung Strategi menyindir secara tidak langsung dengan cara melebih-lebihkan tuturan (Overstate). Hal tersebut dibuktikan dari tuturan tokoh Samsudin yang berlebih-lebihan. Samsudin mengaku berhidup hemat tapi tetap saja miskin namun tuturan miskin di sini berlebihan karena Samsudin dapat membeli barang mewah seperti apartement, mobil ferrari, dan saham.

Ilustrasi ini mewakili fenomena yang terjadi pada masyarakat. Banyak sekali orang yang mengaku miskin tetapi dapat membeli dan memiliki barang-barang mewah. Tuturan pada data 5 maksimalkan kerugian bagi diri sendiri, hal ini terlihat dari tuturan tokoh samsudin yang pengeluarannya mampu membeli apartement, mobil ferrari, dan saham tetapi tokoh samsudin tetap merasa miskin atau dapat dikatakan memaksimalkan kerugian bagi diri sendiri.

\section{Strategi Off Record dengan menggunakan tautologi (Use Tautologies)}

Sindiran yang menggunakan strategi ini tercermin dari adanya pengulangan tuturan tanpa adanya penambahan kejelasan tuturan. Tuturan ini digunakan untuk menuturkan tuturan yang paten dan kebenaran yang diperlukan saja. Penutur lebih menekankan pada sebuah kritik karena adanya pengulangan kata. Arti tautologi dalam KBBI (2007: 1149) adalah berupa pengulangan dalam gagasan, pernyataan atau kata yang berlebih/tidak diperlukan.

Data 6

(3a) Pejabat 1 (jas biru dongker): "Sayang sekali Rangga dimasukan ke dalam sel". (berdiri di belakang seperti seorang pengawal)

(3b) Pejabat 2 (jas hitam): "Gapapa, yang penting tujuan kita untuk mengalihkan isu telah selesai hahaha".

(3c) Pejabat 1: "Bilang sama anggota partai kita. Lain kali kalau mau korupsi jangan gedegede banget, susah untuk bikin pengalihan isu" THE END.

StMy/SOR6/NonSimp/D t2/3b,3c/03.04-03.26

Tuturan pada data 6 dituturkan oleh pejabat 1 dan pejabat 2 . Tuturan terjadi ketika pejabat 1 membaca surat kabar terkait berita jika Rangga, raja dari kerajaan Sunda Emperan dimasukkan dalam sel. Tokoh pejabat 1 dan pejabat 2 merupakan 2 tokoh yang menyarankan Rangga untuk mendirikan sebuah kerajaan guna 
meneyelesaikan permasalahan kasta dengan tokoh Cinta. Namun kemudian pada bagian akhir ternyata tokoh Rangga hanya dijadikan umpan oleh kedua tokoh pejabat sebagai pengalihan isu karena terjadi korupsi besar-besaran yang dilakukan anggota partai dari kedua tokoh pejabat tersebut.

Berdasarkan data nomor 6 pada tuturan $3 \mathrm{c}$ mengandung jenis strategi menyindir secara tidak langsung dengan menggunakan tautologi(Use Tautologies) karena terlihat dari penggunaan kata yang terdapat kata pengulangan secara berlebih pada tuturan 3c "korupsi jangan Gede-gede banget". Maksud dalam tuturan 3c merupakan tuturan untuk menyindir fenomena adanya kerajaan baru di jaman pemerintahan, sehingga dapat sangat mengkhawatirkan untuk terjadinya penipuan, tetapi yang mengaku-aku raja beserta anggota kerajaan tersebut akhirnya dimasukkan ke dalam sel.

Fenomena adanya kerajaan baru ini dimungkinkan ada karena terdapatkan pengalihan isu pada suatu berita. Ilustrasi pada tayangan ini dapat dimungkinkan terjadi sebagai bentuk pengkritisan terhadap suatu. Tuturan ini mamaksimalkan antipati daripada simpati yang terjadi pada tokoh Rangga.

\section{Strategi Off Record dengan menggunakan ironi (Be Ironic)}

Strategi ironi ini merupakan gaya bahasa sindiran yang memiliki maksud berlainan dari apa yang terkandung dalam rangkaian katanya. Menurut Keraf (2000: 143), bahasa yang digunakan adalah bahasa yang halus. Bahasa halus merupakan bahasa yang tersusun secara halus. Dapat dikatakan strategi menyindir yang menggunakan ironi akan dikemas se- elok mungkin, namun bermaksud menyindir atau memberikan ejekan, kritikan terhadap sesuatu secara tidak langsung. Berikut adalah tuturan strategi menyindir secara tidak langsung dengan menggunakan ironi (Be Ironic) yang ditemukan dalam video berjudul "Masuk Polisi Melalui orang dalam".

\section{Data 7}

(1e) Ian : "aku galau nih om..pengen banget tes polisi tapi apa daya aku yang lemah dan polos suci ini mana bisa masuk polisi”.

(1f) Samsudin: "oh ku..kenapa kepikiran pengen jadi polisi? Susah banget tau masuk polisi". StMy/SOR8/NonMode/Dt1/1e, 1f/00.30-00.40

Tuturan tersebut terjadi karena kegalauan tokoh Ian karena sulitnya menjadi polisi dengan jiwa lemah, polos, dan suci. Kemudian, tokoh Samsudin menanggapi kesedihan tokoh Ian dengan pertanyaan terkait alasan Ian untuk menjadi polisi.

Tuturan nomor 7 tersebut termasuk Strategi menyindir secara tidak langsung dengan menggunakan ironi (Be Ironic) karena tuturan tersebut dikemas dengan bahasa yang elok, sopan santun padahal tidak tulus. Terlihat jelas dari tuturan tokoh ian "Pengen banget tes polisi tapi apa daya aku yang lemah dan polos suci ini mana bisa masuk polisi. Tuturan ini bermakna lain dari kata sesungguhnya, ditambah dengan dukungan dari tuturan yang berupa pertanyaan dari tokoh samsudin "oh ku..kenapa kepikiran pengen jadi polisi? Susah banget tau masuk polisi". Dapat dimungkinkan maksud dari tuturan pada data 7 bahwa betapa sulitnya masuk atau mengikuti 
tes seleksi menjadi polisi, masuk polisi akan mudah jika tidak berjiwa lemah dan polos suci.

\section{Strategi off Record dengan menggunakan metafora (Use Metaphors)}

Strategi ini ditandai dengan adanya penggunaan kata yang menggambarkan kata yang membandingkan 2 hal sekaligus, penggambaran antara subjek pertama dan subjek kedua. Berikut adalah tuturan dengan menggunakan strategi tidak langsung use metaphors yang ditemukan pada video berjudul "Sementang Tetangga tapi seenak jidat"

Data 8

(1a) ian : "Ternyata selama ini aku termakan sama berita hoax, katanya nyari masker itu susah, langka. Eh buktinya aku bisa beli banyak masker nih (isi dalam kantung belanjaan ian adalah masker wajah)".

StMy/SOR9/NonAppo/Dt7/1a /01.33-00.26

Tuturan terjadi setelah tokoh Ian keluar dari tempat perbelanjaan. Kemudian, sembari membawa kantung belanjaan tokoh Ian menuturkan keluhannya atas dirinya yang termakan berita "hoax" yang katanya sulit menemukan masker di tengah pandemi. Namun setelah Ian menuturkan kalimat tersebut, ditayangkan isi kantung belanjaan Ian yang ternyata berisi masker wajah dan bukan masker yang berupa kain penutup hidung dan mulut.

Berdasarkan tuturan 1a pada data 14 tersebut, merupakan tuturan strategi menyindir yang menggunakan sindiran secara tidak langsung dengan menggunakan metafora (Use Metaphors), dapat dilihat dari tuturan "ternyata selama ini Aku termakan dengan berita hoax" tetapi maksud sebenarnya bukan berarti tokoh Ian termakan berita hoax. Melainkan berarti sebaliknya, tuturan tersebut ada karena fenomena kelangkaan masker di tengah pandemi dan banyak orang yang berbelanja begitu banyak masker (memborong) sehingga membuaat masker menjadi susah didapat pada semua toko. Tuturan tersebut dapat dimungkinkan terjadi karena fenomena tersebut.

\section{Strategi Off Record dengan menggunakan pertanyaan retoris (Use Retorical)

$\begin{array}{lrr}\text { Strategi } & \text { ini menggunakan } \\ \text { pertanyaan } & \text { retorik } & \text { dengan } \\ \text { mengemukakan } & \text { pertanyaan } & \text { dari } \\ \text { jawaban yang } & \text { mengambang untuk } \\ \text { menyatakan FTA. Penutur menanyakan } \\ \text { pertanyaan yang tidak memerlukan } \\ \text { jawaban, digunakan sebagai ekspresi, } \\ \text { permintaan/informasi } \\ \text { menggunakan kalimat tanya. }\end{array}$

Data 9

(11) Jimin: "Papa.."

(1m) Samsudin: "Apa nak ?"

(1n) Jimin: "Aku udah kenyang ga sanggup lagi makan.."

(10) Samsudin: "Ohku ga boleh gitu, itu namanya mubazir. Kasian tuh nasi nya nangis, habisin makanannya."

(1p) Jimin: "Tapi pa...?"

(1q) Samsudin: "Apa tapi-tapi! Habisin terus"

(1r) Jimin: "Hmmm, baiklah". (langsung balik badan. Kemudian membanting makan beserta piringnya. Jimin langsung menyikut dan meSmackdown 
makanan+piringnya. Ngambil gerakan berkelahi.)

Ian dan Samsudin tercengang kaget.

$$
\begin{array}{r}
\text { StMy/SOR10/NonTact/Dt6/1o, } \\
\text { 1q/01.00-01.15 }
\end{array}
$$

Data 9 dituturkan oleh tokoh Samsudin dan Jimin yang merupakan anak dari Samsudin. Tuturan tersebut diambil dari video yang berjudul "Akibat Salah Penyampaian pada anak_Mubazir". Tuturan tersebut terjadi karena tokoh Jimin tidak sanggup menghabiskan makananya. Kemudian, tokoh Samsudin yang merupakan ayah dari tokoh Jimin memaksa Jimin menghabiskan nasinya. Namun ternyata tokoh Jimin salah memahami tuturan yang disampaikan oleh tokoh Samsudin, kata 'habisi' dimaksud Jimin adalah mengakhiri sedangkan habisi yang dimaksud Samsudin adalah dimakan sampai habis. Kesalahpahaman tokoh Jimin karena tokoh Samsudin tidak memberikan kesempatan tokoh Jimin untuk menjelaskan apa yang akan dituturkannya. Tokoh Samsudin hanya memaksa tokoh Jimin agar segera menghabiskan tanpa adanya bantahan.

Tuturan pada data 9 merupakan tuturan Strategi menyindir secara tidak langsung dengan menggunakan metafora (Use Metaphors) karena tuturan Samsudin kepada tokoh Jimin yang merupakan anaknya, mempergunakan tuturan yang berupa pertanyaan tetapi tidak memerlukan jawaban/retorik. Hal ini terlihat dalam tuturan samsudin "Apa tapi-tapi!, habisin terus". Tuturan (1q) dapat dimungkinkan merupakan tuturan menyindir fenomena orang tua yang selalu harus dituruti tanpa adanya bantahan dari anak meskipun sang anak bermaksud untuk menjelaskan keluhkesah seorang anak atau sekadar bertanya terkait yang dibingungkan oleh seorang anak.

\section{Strategi Off Record dengan menyatakan sesuatu dengan samar - samar (Be Vague)}

Strategi ini menggunakan ungkapan yang samar-samar. Brown dan Levinson (1987: 226) mengemukakan bahwa strategi ini untuk menyamarkan objek FTA/ pelanggaran yang dilakukan. Penutur tidak bisa direkam dengan FTA karena tidak jelas siapa objek FTA/apa pelanggaran yang dilakukan. Strategi ini digunakan untuk informasi yang tidak jelas/samar.

\section{Data 10}

(1h) Samsudin: "Banyak banget udah ku tes sana sini, jangankan polisi, poligami juga pernah $\mathrm{ku}$ tes. Tapi karena aku setia, gak jadi poligami'

(1i) Ian: "Susah ya om tes polisi?"

(1j) Samsudin: "Iyalah...cukup berat susah !. Kalo mau masuk polisi kita harus ada orang dalam tau"

(1k) Ian: "Loh eh? Kok harus ada orang dalem?"

(2a) Samsudin : (Terdengar langkah kaki samsudin yang menghampiri polisi, yang tengah berjaga berdiri di depan pintu.) "Misi pak..saya mau tes masuk polisi.

(2b) Polisi : "Maaf..gak ada orang di dalem, soalnya lagi jam istirahat".

StMy/SOR12/agre/Dt1/1j,2b/

00.45-01.15 
Tuturan bernomor 10 tersebut diambil dari video berjudul "Masuk polisi melalui orang dalam_TesPolisi". Tuturan tersebut terjadi karena keinginan tokoh Ian yang ingin menjadi polisi kemudian tokoh Ian bertanya kepada tokoh Samsudin apakah susah. Tokoh Samsudin memberi jawaban jika memang susah karena perlu ada orang dalam. Namun yang dimaksud orang dalam tayangan tersebut adalah makna dalam sesungguhnya bukan makna dalam yang merupakan bantuan dari petugas polisi yang sudah bekerja menjadi polisi.

Data 10 mengandung Strategi menyindir secara tidak langsung dengan menyatakan sesuatu dengan samar-samar (Be Vague) karena adanya tuturan yang menggunakan ungkapan samar-samar atau tidak jelas. Hal ini dapat dilihat pada tuturan $1 \mathrm{j}$ yang dituturkan secara berlebih-lebihan "iyalah...cukup berat susah!. Kalo mau masuk polisi kita harus ada orang dalam tau". Ilustrasi tersebut cukup dapat mewakili fenomena yang terjadi pada masyarakat, yang jika akan melakukan atau masuk polisi akan mudah jika punya kenalan/saudara yang sudah bekerja menjadi polisi. Namun ilustrasi tersebut dikemas dengan sindiran sedemikian rupa baik dengan tuturan yang memiliki makna samar, misalnya dari kata'orang dalam' yang sebenarnya memiliki makna lain yakni tidak ada orang/petugas di dalam kantor polisi karena sedang jam istirahat.

\section{Strategi Off Record dengan menyatakan penyeragaman/ menggenaralisasi (Over Generalize)}

Dalam strategi ini penutur hanya akan memberi informasi yang bersifat umum dan tidak memberi informasi tersebut secara jelas.
Misalnya, ketika ada beberapa peraturan maka keputusan untuk menetapkan peraturan yang akan diterapkan pad dirinya sendiri keputusan tersebut sepenuhnya lawan tutur yang menentukan. Pengeneralisasian dalam strategi ini dilakukan secara berlebihan untuk menghindari FTA dengan mengemukakan peraturan umum.

Data 11

(2c) Ian: "Oh iyaa makasih banyak yaa om. Uangnya belakangan"

(2d) Samsudin: "Keginilah sifat orang-orang. Sementang tetangga dan udah dekat. Bayar belakangan. Bukan dibayarnya di depan" (ongkos ojek ian di taruh di tempat duduk belakang)". StMy/SOR13/NonAgre/Dt7/ $2 \mathrm{c}, 2 \mathrm{~d} / 01.23-01.37$

Tuturan tersebut diambil dari video berjudul "Sementang Tetangga tapi seenak jidat". Tuturan pada data nomor 11 tersebut terjadi setelah tokoh Ian sampai di tujuan dengan ojek yang ternyata tetangganya sendiri. Tokoh Ian menaiki ojek dari tokoh Samsudin dan tidak memberikan uang/ongkos pada tokoh Samsudin di depan. Kemudian tokoh Samsudin mengeluh karena tokoh Ian.

Tuturan pada data bernomor 11 ini mengandung strategi menyindir secara tidak langsung dengan penyeragaman/ menggeneralisasikan karena adanya pengeneralisasian secara berlebihan untuk menghindari FTA dengan mengemukakan sesuatu yang umum "Oh iyaa makasih banyak yaa om. Uangnya belakangan". Tuturan tersebut di kemas seolah tokoh Ian 
melakukan kesalahan dengan bertindak sesuka hati karena melakukan pembayaran/ongkos ojek di belakang. Padahal verba 'bayarnya belakangan' yang dimaksud dalam tayangan ini adalah bayarnya di belakang punggung pengemudi bukan dalam artian berhutang. Ilustrasi ini digunakan untuk untuk menyindir fenomena yang terjadi dilingkungan masyarakat yang ketika sudah bertetangga atau sudah kenal maka orang dapat bertindak sesuka hati. Padahal, seharusnya tidak baik bersikap demikian.

\section{Strategi Off Record dengan menggantikan posisi lawan tutur (DisplaceH)}

Strategi ini menggantikan lawan tutur dengan mengalamatkan FTA pada seseorang yang tidak terancam mukanya. Strategi ini juga tidak mengacu ke lawan tutur secara langsung. Strategi ini menggantikan posisi lawan tutur ini mempergunakan penutur agar menunjukan ujaran kepada lawan tutur yang sebenarnya bukan yang dimaksud yang tidak terancam mukanya.

Data 12

(1j) Samsudin: "Ya ampun pasti seru sangat nih. Bosan banget Om di rumah karena ga boleh keluar rumah. Ngikutin anjuran pemerintah. Yaudah kita mabar aja yok sekarang".

StMy/SOR14/Appo/Dt8/1j/00 $.55-01.05$

Tuturan ini diambil dari video berjudul "Mobile Legend Animation_mabar di rumah". Data tersebut dituturkan oleh tokoh Samsudin dalam menanggapi tokoh Ian yang menjelaskan terkait game Mobile Legend yang sedang dimainkan selama di rumah aja karena mengikuti anjuran pemerintah. Tokoh Samsudin bertutur demikian, bukan hanya menggapi tuturan tokoh Ian melainakan juga ungkapan karena kebosanan selama di rumah tanpa melakukan apa-apa. Ajakan untuk bermain game mobile legend bersama tokoh Ian sebagai referensi untuk mengatasi kebosanan selama di rumah karena mengikuti anjuran pemerintah.

Dari data bernomor 12 adalah Strategi menyindir secara tidak langsung dengan menggantikan posisi lawan tutur (Displace $H$ ) karena pengganti lawan tutur, yakni dapat dilihat dari kesuntukan yang dialami tokoh samsudin yang dapat dimungkinkan hal tersebut digunakan untuk menyindir fenomena yang terjadi pada masyarakat dan untuk menyindir fenomena kebanyakan manusia yang harus di rumah saja selama pandemi karena adanya peraturan yang dikeluarkan pemerintah agar tetap di rumah. Meskipun dikemas dengan adanya game mobile legend dapat menghilangkan kesuntukan namun maksud sebenarnya adalah untuk menyindir fenomena yang terjadi di masyarakat. Tuturan (1j) merupakan tuturan yang menunjukan ujaran kepada orang lain tetapi dibungkus sedemikian rupa, sindirann tersebut merupakan efek dari aturan pemerintah yang melarang warga/penduduk indonesia tidak keluar rumah. Larangan tersebut menjadikan orang bosan karena berdiam diri di rumah, sehingga tokoh samsudin bertutur demikian dimungkinkan untuk mewakili suara hari banyak orang. 


\section{Relevansi Strategi Sindiran pada Video Youtube Sengklekman Official dalam Pembelajaran Bahasa Indonesia}

Dalam pembelajaran Bahasa Indonesia, hasil analisis tentang strategi menyindir ini dapat digunakan sebagai alternatif bahan pengayaan dalam pembelajaran teks anekdot. Mahsun (2014) menyatakan bahwa teks anekdot adalah salah satu jenis teks cerita yang menampakkan reaksi pelaku atas peristiwa secara eksplisit. Lebih lanjut, dinyatakan bahwa teks anekdot adalah cerita singkat yang menarik karena lucu dan mengesankan, biasanya mengenai orang penting atau terkenal dan berdasarkan kejadian yang sebenarnya. Teks anekdot tidak harus mengenai orang penting dan tidak harus kejadian yang sebenarnya (Kemdikbud, 2014). Teks yang memuat unsur humor dan dibuat dengan tujuan menyindir pihak tertentu. Hal tersebut sesuai dengan hasil pembahasan mengenai strategi menyindir pada video Sengklekman Official yang berisi kartun hiburan namun memiliki maksud mencubit, mengingatkan, atau menggugat kehidupan sosial, dinamika politik, dan lingkungan.

Teks ini diajarkan pada jenjang SMA/SMK/MA/MAK kelas $\mathrm{X}$ semester 1. Sesuai dengan kurikulum 2013, Kompetensi Dasar yang perlu dicapai dalam teks ini adalah 3.5, 4.5, 3.6, dan 4.6. keempat KD tersebut meliputi (3.5) mengevaluasi teks anekdot dari aspek makna tersirat; (4.5) mengonstruksi makna tersirat dalam sebuah teks anekdot baik lisan maupun tulisan; (3.6) menganalisis struktur dan kebahasaan teks anekdot; dan (4.6) menciptakan kembali teks anekdot dengan memerhatikan struktur, dan kebahaasn baik lisan maupun tulis.

\section{PENUTUP}

Berdasarkan hasil penelitian, ditemukan penggunaan strategi off record pada beberapa jenisnya, yaitu 2 data strategi give hint, 2 data give association clues, 1 data presuppose, 1 data understate, 4 data overstate, 1 data use tautologies, 2 data be ironic, 1 data use metaphors, 1 data use retorical question, 1 data be vague, 1 data give over-generalize, dan 4 data displace $H$. Di antara strategi menyindir yang digunakan, strategi off record overstate dan displace $H$ adalah yang paling dominan. Hal tersebut dikarenakan dalam tayangan pada video sengklekman official lebih dominan mengarah pada tuturan yang berlebihlebihan dan mengandung tuturan yang tidak mengacu kepada lawan tutur secara langsung.

\section{DAFTAR PUSTAKA}

Brown, Penelope dan Stephen C. Levinson. (1987). Politeness: Some Universal in Language Usage. Cambridge: University Of Cambridge Press.

Davis, J. M. (Ed.). (2017). Satire and Politics: The Interplay of Heritage and Practice (Palgrave S). New York: Palgrave Macmillan.

Ezell, S. K. (2016). Humor and Satire on Contemporary Television: Animation and the American Joke (The Cultur). New York: Routledge.

Kementrian Pendidikan dan Kebudayaan Republik Indonesia. (2014). Bahasa Indonesia Ekspresi Diri dan Akademik, SMA/SMK Kelas $X$. Jakarta: Pusat Kurikulum dan Perbukuan, Balitbang, Kemdikbud. 
Melton, J. (2018). When the Candle Goes Out: The Complexity of Simple Jokes and the Limits of Satire. Studies in American Humor, 4(2), 152-159. http://doi.org/10.5325/studamerh $\underline{\text { umo r.4.2.0152 }}$

Mahsun. (2014). Teks dalam Pembelajaran Bahasa Indonesia Kurikulum 2013. Jakarta: PT Raja Grafindo Persada.

Moleong, Lexy J. (2013). Metode Penelitian Kualitatif Edisi Revisi. Bandung: PT. Remaja Rosdakarya.

Nadar, FX. (2009). Pragmatik \& Penelitian Pragmatik. Yogyakarta: Graha Ilmu.

Rowden, C. (2013). Memorialisation, Commemoration and Commodification: Massenet and Caricature. Cambridg.
Sugiyono. (2016). Metode Penelitian Kualitatif, Kuantitatif, dan $R \& D$. Bandung: Alfabeta.

Suprayuni, Diana dan Anik Juwariyah. (2019). Humor dan Satire Kartun Media Massa sebagai Komunikasi Visual di Era Disrupsi. Jurnal Avant Garde: Jurnal Ilmu Komunikasi 07 (2), 187-202.

https://journal.budiluhur.ac.id/in dex.php/avantgarde/article/view/ 919/pdf_30

Weisgerber, J. (2019). Satire and Irony as Means of Communication. Comparative Literature Studies, 10(2), 157-172. 